\title{
PEMANFAATAN SERAT DAUN PANDAN DURI SEBAGAI CAMPURAN DALAM PENINGKATAN KARAKTERISTIK GENTENG BETON
}

\author{
Mukti Hamzah Harahap dan Evri Yani Purba \\ Jurusan Fisika FMIPA Universitas Negeri Medan \\ Evriyani@gmail.com
}

\begin{abstract}
ABSTRAK
Penelitian ini bertujuan untuk mengetahui pengaruh komposisi serat daun pandan duri terhadap karakteristik genteng beton, mengetahui hasil pengujian sifat mekanik kekuatan lentur dan kekuatan impak serta pengujian sifat fisis daya serap air dan daya serap panas pada genteng beton dengan variasi campuran serat daun pandan duri 2,5\%; $5,0 \% ; 7,5 \%$ dan beton normal.

Genteng beton dibuat berbentuk balok sesuai standart ASTM untuk pengujian sifat mekanik kekuatan lentur dan kekuatan impak serta genteng beton berbentuk genteng sesuai standart SNI untuk pengujian sifat fisis daya serap air dan daya serap panas. Dari hasil pengujian sifat mekanik yaitu kekuatan lentur diperoleh genteng beton variasi serat daun pandan duri yang memenuhi syarat mutu ASTM D-790 pada komposisi 2,5\% dan 5\% serat daun pandan duri yaitu sebesar $(13,15 \pm 0,26) \mathrm{Nmm}^{-2}$ dan $(9,96 \pm 0,72) \mathrm{Nmm}^{-2}$. Dari hasil pengujian sifat mekanik yaitu kekuatan impak diperoleh genteng beton variasi serat daun pandan duri yang yang memenuhi syarat mutu ASTM D-256 pada 5\% dan $7,5 \%$ serat daun pandan duri yaitu sebesar $(4950 \pm 638,35) \mathrm{Joule} / \mathrm{m}^{2}$ dan $(6850$ $\pm 526,78) \mathrm{Joule} / \mathrm{m}^{2}$. Dari hasil pengujian sifat fisis yaitu penyerapan air pada genteng beton variasi serat daun pandan duri yang memenuhi syarat SNI 0096:2007 adalah pada campuran $0 \%$ yaitu $(7,53 \pm 0,76 \%) ; 2,5 \%$ yaitu $(5,06$ $\pm 0,70 \%)$ dan $5,0 \%$ yaitu $(4,96 \pm 0,96 \%$.). Pada daya serap panas genteng beton variasi serat daun pandan duri yang memenuhi syarat SNI 0096:2007 adalah pada campuran $0 \%$ yaitu $(74,3 \pm 0,86 \%) ; 2,5 \%$ yaitu $(73,86 \pm$ $0,91 \%) ; 5,0 \%$ yaitu $(73,09 \pm 1,01 \%)$ dan $7,5 \%$ yaitu $(71,17 \pm 0,90 \%)$. Hal ini merupakan bahwa semakin besar penambahan serat daun pandan duri pada genteng beton dapat meningkatkan karakteristik genteng beton.
\end{abstract}

Kata Kunci : Serat Daun Pandan Duri, Genteng Beton, Sifat Mekanik

Pendahuluan

Atap adalah pelindung rangka atap suatu bangunan secara keseluruhan terhadap pengaruh cuaca : panas, hujan, angin dan sebagainya. Dengan banyaknya gedung-gedung yang dibangun maka sangat dibutuhkan bahan penutup atap yang baik, yaitu penutup atap yang memenuhi persyaratan kuat, ringan dan kedap air.

Genteng beton merupakan salah satu penutup atap yang baik, namun tidak banyak masyarakat yang menggunakan genteng beton, selain harganya yang relatif mahal bila dibandingkan dengan genteng lain. 
Genteng beton juga termasuk penutup atap yang cukup berat, sehingga memerlukan konstruksi rangka atap yang kuat agar dapat menahan berat genteng.

Usaha peningkatan kualitas genteng beton masih terus dilakukan baik peningkatan kuat tekan, tarik maupun lentur, bahkan sampai upaya untuk membuat genteng beton itu ringan tetapi mempunyai kekuatan tinggi. Penambahan serat dalam adukan genteng beton ditujukan untuk meningkatkan kuat tarik, kuat lentur, dan genteng beton yang dihasilkan lebih ringan. Selain itu juga berguna untuk mengurangi penggunaan pasir.

Dalam beberapa penelitian sebelumnya seperti penelitian Deli Natalia Saragih (2007) tentang pembuatan genteng beton yang dicampur dengan serat daun nenas. Didapat hasil pengujian sifat mekanis kekuatan lentur yang optimal pada variasi serat $0,15 \%$ sebesar 131,5 $\mathrm{kg} / \mathrm{cm}^{2}$. Kuat impak yang optimal didapatkan pada variasi serat 0,3\% sebesar $8,13 \mathrm{KJ} / \mathrm{m}^{2}$. Sedangkan pada penelitian Wiyadi (1999) tentang pembuatan genteng beton menggunakan serat ijuk memiliki berat genteng 4.936, 4.727, 4.696, 4.625, 4.563 dan 4.554 gram dengan berat genteng rata-rata 4.683,5 gram. Dan pada penelitian Rosadhan (2000) menggunakan serat serabut kelapa memiliki berat genteng $4.501 ; 4.440$; $4.377 ; 4.285$ dan 4.141 gram dengan berat genteng rata-rata $4.348,8$ gram.

Dari hasil penelitian ini genteng beton yang dihasilkan masih memiliki bobot yang berat. Itu dapat dilihat dari jenis serat yang digunakan. Dimana penggunaan serat serabut kelapa yang memiliki massa jenis $1,125 \mathrm{gr} / \mathrm{cm}^{3}$ menghasilkan genteng beton yang lebih ringan dibanding dengan penggunaan serat ijuk yang memiliki massa jenis $1,136 \mathrm{gr} / \mathrm{cm}^{3}$. Sehingga penulis tertarik untuk membuat genteng beton dengan campuran serat daun pandan duri yang memiliki massa jenis yang lebih kecil yaitu $0,96 \mathrm{gr} / \mathrm{cm}^{3}$ untuk meningkatkan karakteristik genteng beton dan menghasilkan genteng yang lebih ringan.

Selain itu pemilihan serat daun pandan duri sebagai bahan pembuatan genteng beton yaitu karena : pengadaannya cukup mudah sehingga bila ditinjau dari segi ekonomis akan lebih menguntungkan, serat daun pandan duri mempunyai kemampuan tarik yang cukup sehingga diharapkan dapat mengurangi retak, dapat meningkatkan kuat tarik, kuat lentur, dan beton yang dihasilkan lebih ringan. Juga pada serat daun pandan duri memiliki kandungan Lignin (18-22 \%), Selulosa (83-88\%), Holoselulosa (37$76 \%$ ) dimana lignin berfungsi sebagai perekat untuk mengikat sel bersamasama sedangkan selulosa berfungsi memberikan ketegaran pada sel sehingga dapat meningkatkan kekuatan tarik dan kelenturan bahan.

Berdasarkan uraian di atas maka penulis tertarik untuk melakukan penelitian yang berjudul : "Pemanfaatan Serat Daun Pandan Duri Sebagai Campuran dalam Peningkatan Karakteristik Genteng Beton”.

\section{Genteng Beton}

Menurut SNI 0096:2007 genteng beton atau genteng semen adalah unsur bangunan yang dipergunakan untuk atap terbuat dari campuran merata antara semen Portland atau sejenisnya dengan 
agregat dan air dengan atau tanpa menggunakan pigmen.

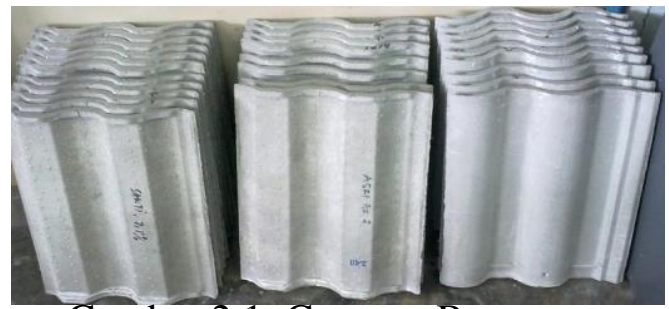

Gambar 2.1. Genteng Beton

(Supatmi, 2011)

Genteng beton telah lama dikenal di Indonesia, sejak sebelum perang Dunia II. Awalnya genteng beton dibuat oleh perusahaan Australia, dengan nama genteng Monier. Nama monier berasal dari nama seorang tukang kebun di Paris, yang pertama menggunakan pot tanaman dari beton sebagai pengganti pot dari kayu yang lekas rusak.

Disebut genteng beton karena genteng ini dibuat dari campuran semen Portland dan pasir yang sama dengan material penyusun beton umumnya.

\section{Serat Pandan Duri}

Serat pandan termasuk golongan jenis serat alami (natural fiber) yang berasal dari suku Pandanaceae yang tumbuh di pesisir pantai. Tanaman pandan terdiri dari batang, daun, bunga, buah, biji, dan akar, yang merupakan salah satu jenis tanaman semak, perdu atau pohon dengan batang berupa liana dengan batang-batang memanjat yang mempunyai tinggi sekitar $11 \mathrm{~m}$. Jenis tanaman pandan yang digunakan dalam penelitian ini adalah tanaman pandan duri atau Pandanus tectorius (Tjitrosoepomo, 2007).
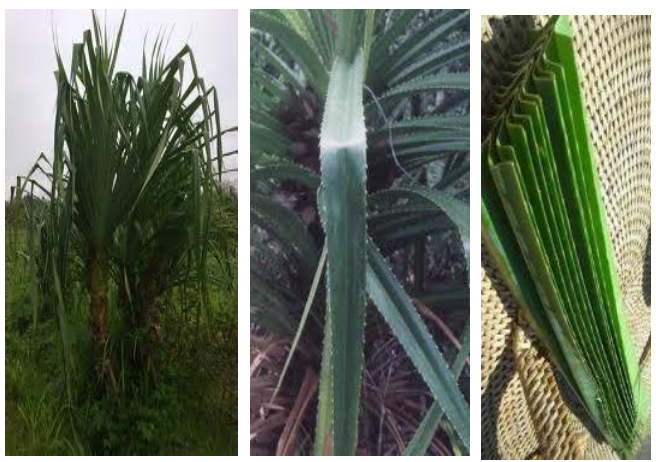

Gambar 2.2. Pandan duri

\section{Komponen Kimia Pandan Duri}

Lignin berfungsi sebagai perekat untuk mengikat sel bersamasama. Dalam dinding sel, lignin sangat erat hubungannya dengan selulosa dan berfungsi memberikan ketegaran pada sel. Kandungan lignin serat daun pandan duri berkisar antar 18-22 \%.

Selulosa mempunyai fungsi untuk memberikan kekuatan tarik pada suatu sel, karena adanya ikatan kovalen yang kuat pada cincin piranosa dan antar unit gula penyusun selulosa. Kandungan selulosa pada serat daun pandan duri berkisar antara 83-88\%. Selanjutnya kadar holoselulosa daun pandan yaitu pada selang 37-76 \% . (Ina Dan Totok, 2006 dalam http://andre4088.blogspot.com).

\section{Metode Penelitian}

\section{Uji Kekuatan Lentur (UFS)}

Pengujian kekuatan lentur dimaksud untuk megetahui ketahanan komposit terhadap pembebanan pada tiga titik lentur. 


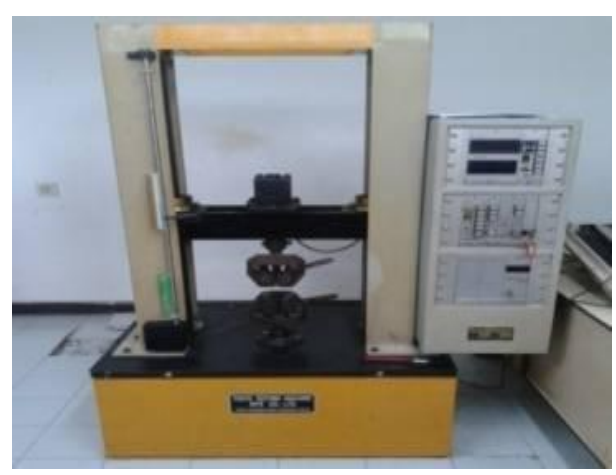

Gambar 2.3. Mesin Uji Lentur

Besar tegangan lentur adalah:

$$
\sigma(\text { UFS })=\frac{M}{W}=\frac{P L}{4 W}
$$

dimana luas penampang untuk segi empat adalah:

$$
W=\frac{b d^{2}}{6}
$$

Maka tegangan lentur untuk segi empat adalah :

$$
U F S=\frac{\mathbf{3} P L}{\mathbf{2} b \boldsymbol{h}^{\mathbf{2}}}
$$

\section{Dengan :}

$$
\begin{aligned}
\mathrm{UFS}= & \text { Kekuatan lentur }\left(\mathrm{Nm}^{-2}\right) \\
\mathrm{P}= & \text { Beban maksimum pematah } \\
& \text { sampel }(\mathrm{N}) \\
\mathrm{b}= & \text { Lebar sampel uji }(\mathrm{m}) \\
\mathrm{h}= & \text { Tebal sampel uji }(\mathrm{m}) \\
\mathrm{L}= & \text { Jarak span }(\mathrm{m})
\end{aligned}
$$

\section{Uji Impak (impact test )}

Pengujian impak bertujuan mengetahui ketangguhan suatu bahan terhadap pembebanan dinamis, sehingga dapat diketahui apakah suatu bahan yang diuji rapuh atau kuat.

Kekuatan impak (Is) yang dihasilkan merupakan perbandingan antara energi yang diserap sampel (Es) dengan luas penampang.

Dengan:

$\mathrm{E}=\mathrm{m} \cdot \mathrm{g} \cdot \mathrm{h}\left(\cos \Theta_{2}-\cos \Theta_{1}\right)$
Dimana :

$\mathrm{m} \quad=$ massa pendulum $(\mathrm{kg})$

$\mathrm{g} \quad=$ gravitasi bumi $\left(\mathrm{m} / \mathrm{s}^{2}\right)$

$\mathrm{h} \quad=$ tinggi pendulum $(\mathrm{m})$

$\cos \theta_{1}=$ sudut awal pendulum

$\cos \theta_{2}=$ sudut pendulum setelah pendulum menumbuk beban,

sehingga:

$$
\text { Is }=\frac{E s}{A}
$$

Dengan :

Es = Energi serap (Joule)

$\mathrm{A}=$ Luas penampang $\left(\mathrm{m}^{2}\right)$

$\mathrm{A}=\mathrm{b} \times \mathrm{d}$

Is = Kekuatan impak $\left(\mathrm{Joule} / \mathrm{m}^{2}\right)$

$\mathrm{b} \quad=\operatorname{Lebar}$ sampel $(\mathrm{m})$

\section{Uji Penyerapan Air}

Pengujian ini dilakukan untuk mengetahui banyaknya air yang diserap oleh genteng beton partikel setelah direndam pada periode tertentu.

Besar daya serap air untuk genteng tidak boleh lebih $10 \%$ (SNI 0096:2007). Dan dapat dihitung dengan menggunakan persamaan sebagai berikut:

Daya Serap Air $=\frac{W-K}{K} \times 100$

Dengan:

$\mathrm{W}$ : berat genteng dalam keadaan basah (gr)

$\mathrm{K}$ : berat genteng dalam keadaan kering (gr) (Supatmi, 2011)

\section{Uji Penyerapan Panas}

Pengujian ini dilakukan untuk mengetahui hasil dari penyerapan panas genteng beton, apakah genteng beton yang dihasilkan menimbulkan panas ruang di dalamnya ataukah tidak. 
Persentase perbedaan suhu. Dihitung dari data yang diperoleh dengan menggunakan rumus :

$$
\frac{T_{2}}{T_{1}} \times 100 \%
$$

$$
\begin{array}{rlr}
\mathrm{T}_{1}= & \text { termometer atas (dengan } \\
& \text { benda uji) } & \\
\mathrm{T}_{2}= & \text { termometer } & \text { bawah } \\
& \text { (kosong) } &
\end{array}
$$

(Supatmi, 2011)

dimana :

\begin{tabular}{|c|c|c|c|c|c|c|c|c|}
\hline $\begin{array}{l}\text { Komposisi } \\
\text { Serat }\end{array}$ & $\begin{array}{c}\text { Kode } \\
\text { Sampel }\end{array}$ & $\begin{array}{l}\text { Beban } \\
\text { Maks P } \\
(\mathrm{N})\end{array}$ & $\begin{array}{l}\text { Beban } \\
\text { Maks } \\
\text { Rata- } \\
\text { rata }(\mathrm{N})\end{array}$ & $\begin{array}{c}\Delta \\
(\mathrm{mm})\end{array}$ & $\begin{array}{c}3 \mathrm{PL}(\mathrm{N} \\
\mathrm{mm})\end{array}$ & $\begin{array}{c}2 \mathrm{bh}^{2} \\
\left(\mathrm{~mm}^{3}\right)\end{array}$ & $\begin{array}{c}\text { UFS (N } \\
\left.\mathrm{mm}^{-2}\right)\end{array}$ & $\begin{array}{l}\text { Rata- } \\
\text { rata } \\
\text { UFS (N } \\
\left.\mathrm{mm}^{-2}\right)\end{array}$ \\
\hline \multirow{3}{*}{$0 \%$} & A11 & 11,95 & \multirow{3}{*}{13,55} & 1,62 & 6094,5 & 4000 & 1,52 & \multirow{3}{*}{1,72} \\
\hline & A12 & 13,83 & & 1,79 & 7053,3 & 4000 & 1,76 & \\
\hline & A13 & 14,86 & & 1,81 & 7578,6 & 4000 & 1,89 & \\
\hline \multirow{3}{*}{$2,5 \%$} & A21 & 103,37 & \multirow{3}{*}{103,14} & 10,14 & 52718,7 & 4000 & 13,17 & \multirow{3}{*}{13,15} \\
\hline & A22 & 105,12 & & 9,86 & 53611,2 & 4000 & 13,40 & \\
\hline & A23 & 100,93 & & 10,11 & 51474,3 & 4000 & 12,87 & \\
\hline \multirow{3}{*}{$5,0 \%$} & A31 & 75,42 & \multirow{3}{*}{65,5} & 9,10 & 38464,2 & 4000 & 9,61 & \multirow{3}{*}{9,96} \\
\hline & A32 & 78,13 & & 8,37 & 39846,3 & 4000 & 9,96 & \\
\hline & A33 & 80,95 & & 8,54 & 41284,5 & 4000 & 10,32 & \\
\hline \multirow{3}{*}{$7,5 \%$} & A41 & 40,65 & \multirow{3}{*}{38,8} & 7,85 & 20731,5 & 4000 & 5,18 & \multirow{3}{*}{4,94} \\
\hline & A42 & 39,98 & & 7,67 & 20389,8 & 4000 & 5,09 & \\
\hline & A43 & 35,77 & & 7,73 & 18242,7 & 4000 & 4,56 & \\
\hline \multicolumn{9}{|c|}{$\begin{array}{l}\text { Beban Maksimum }=200 \mathrm{kgf} \\
\text { Jarak Sangga } L=170 \mathrm{~mm} \\
\text { Lebar sampel uji } b=20 \mathrm{~mm} \\
\text { Tebal sampel uji } \mathrm{h}=10 \mathrm{~mm}\end{array}$} \\
\hline
\end{tabular}

\section{Hasil Penelitian dan Pembahasan}

\section{Kekuatan Lentur}

Tabel 4.1. Pengujian Beban Lentur Genteng Beton dengan Penambahan Serat daun pandan duri dan Pengurangan Pasir

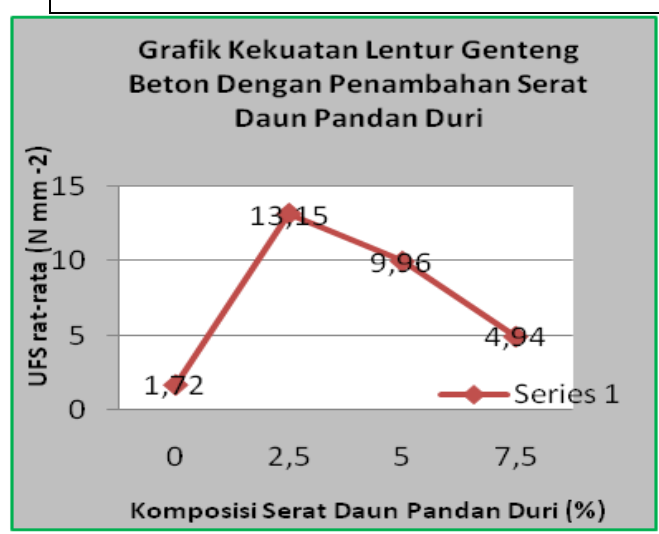

Gambar 4.1. Grafik Kekuatan Lentur Genteng Beton Dengan Penambahan Serat Daun Pandan Duri
Jika dilihat tabel 4.1 kekuatan lentur sampel menggunakan serat jauh lebih besar $\left(4,56-13,40 \mathrm{~N} \mathrm{~mm}^{-2}\right)$ dari pada sampel tanpa menggunakan serat daun pandan duri $\left(1,52-1,89 \mathrm{~N} \mathrm{~mm}^{-2}\right)$ 


\section{Kekuatan Impak}

Tabel 4.2. Pengujian Kekuatan Impak Genteng Beton dengan Penambahan Serat daun pandan duri dan Pengurangan Pasir

\begin{tabular}{|c|c|c|c|c|c|c|c|c|c|}
\hline \multirow{2}{*}{$\begin{array}{c}\text { Kompo- } \\
\text { sisi } \\
\text { Serat }\end{array}$} & \multirow{2}{*}{$\begin{array}{c}\text { Kode } \\
\text { Sampel }\end{array}$} & \multicolumn{3}{|c|}{ Dimensi Sampel } & \multirow{2}{*}{$\begin{array}{c}\text { Luas } \\
\text { Penamp } \\
\text { ang A } \\
\left(\mathrm{m}^{2}\right)\end{array}$} & \multirow{2}{*}{$\begin{array}{c}\text { Energi } \\
\text { Serap } \\
\text { Es } \\
\text { (Joule) }\end{array}$} & \multirow{2}{*}{$\begin{array}{c}\text { Energi } \\
\text { Serap } \\
\text { Rata-rata } \\
\text { (Joule) }\end{array}$} & \multirow{2}{*}{$\begin{array}{c}\text { Kekuatan } \\
\text { Impak Is } \\
\text { (Joule/m² } \\
\text { ) }\end{array}$} & \multirow{2}{*}{$\begin{array}{l}\text { Kekuatan } \\
\text { Impak Is } \\
\text { Rata-rata } \\
\left(\text { Joule } / \mathrm{m}^{2}\right)\end{array}$} \\
\hline & & $\begin{array}{c}\text { Panjang } \\
\mathrm{P}(\mathrm{m})\end{array}$ & $\begin{array}{c}\text { Lebar l } \\
\text { (m) }\end{array}$ & $\begin{array}{c}\text { Tebal t } \\
\text { (m) }\end{array}$ & & & & & \\
\hline \multirow{3}{*}{$0 \%$} & B11 & 0,1 & 0,02 & 0,01 & 0,0002 & 0,27 & \multirow{3}{*}{0,24} & 1350 & \multirow{3}{*}{1216,67} \\
\hline & B12 & 0,1 & 0,02 & 0,01 & 0,0002 & 0,25 & & 1250 & \\
\hline & B13 & 0,1 & 0,02 & 0,01 & 0,0002 & 0,21 & & 1050 & \\
\hline \multirow{3}{*}{$2,5 \%$} & B21 & 0,1 & 0,02 & 0,01 & 0,0002 & 0,32 & \multirow{3}{*}{0,54} & 1600 & \multirow{3}{*}{2700} \\
\hline & $\mathrm{B} 22$ & 0,1 & 0,02 & 0,01 & 0,0002 & 0,50 & & 2500 & \\
\hline & B23 & 0,1 & 0,02 & 0,01 & 0,0002 & 0,80 & & 4000 & \\
\hline \multirow{3}{*}{$5,0 \%$} & B31 & 0,1 & 0,02 & 0,01 & 0,0002 & 0,96 & \multirow{3}{*}{0,99} & 4800 & \multirow{3}{*}{4950} \\
\hline & B32 & 0,1 & 0,02 & 0,01 & 0,0002 & 0,88 & & 4400 & \\
\hline & B33 & 0,1 & 0,02 & 0,01 & 0,0002 & 1,13 & & 5650 & \\
\hline \multirow{3}{*}{$7,5 \%$} & B41 & 0,1 & 0,02 & 0,01 & 0,0002 & 1,26 & \multirow{3}{*}{1,37} & 6300 & \multirow{3}{*}{6850} \\
\hline & B42 & 0,1 & 0,02 & 0,01 & 0,0002 & 1,38 & & 6900 & \\
\hline & B43 & 0,1 & 0,02 & 0,01 & 0,0002 & 1,47 & & 7350 & \\
\hline
\end{tabular}

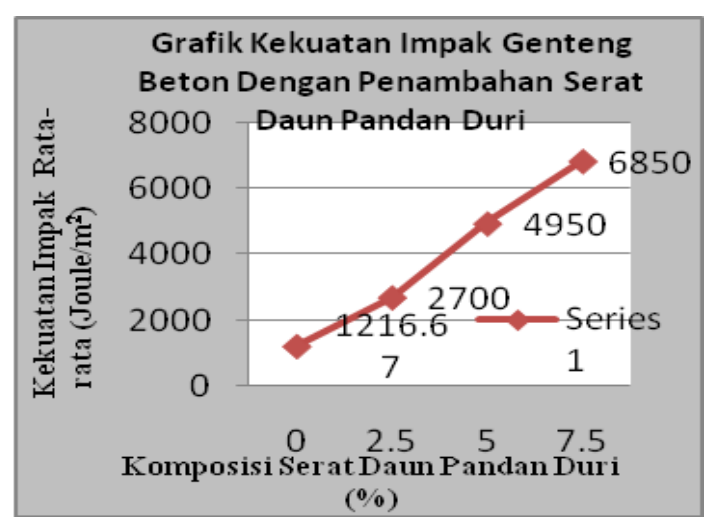

Gambar 4.2. Grafik Kekuatan Impak Genteng Beton Dengan Penambahan Serat Daun Pandan Duri

Nilai yang didapatkan berbeda untuk setiap persentase komposisi serat yang berbeda-beda. Semakin besar persentase komposisi serat maka semakin besar kekuatan impak, ini dapat dilihat dari persentase komposisi serat yang terbesar 7,5\% sebesar $6850 \quad$ Joule $/ \mathrm{m}^{2}$, sedangkan persentase komposisi serat semakin kecil maka kekuatan impak semakin berkurang, ini dapat dilihat dari persentase komposisi serat yang terkecil 2,5\% sebesar 2700 Joule $/ \mathrm{m}^{2}$. Telah diperoleh kekuatan impak rata-rata yang tertinggi berturut-turut pada persentase serat $5,0 \%$ dan 7,5\% yaitu sebesar 4950 Joule $/ \mathrm{m}^{2}$ dan $6850 \mathrm{Joule} / \mathrm{m}^{2}$ dan hasil ini memenuhi syarat mutu ASTM

D-256. 


\section{Pengujian Penyerapan Air}

Tabel 4.3. Pengujian Penyerapan Air Genteng Beton dengan Penambahan Serat daun pandan duri dan Pengurangan Pasir

\begin{tabular}{|c|c|c|c|c|c|}
\hline $\begin{array}{c}\text { Komposisi } \\
\text { Serat }\end{array}$ & $\begin{array}{c}\text { Kode } \\
\text { Sampel }\end{array}$ & $\begin{array}{c}\text { Massa } \\
\text { Basah } \\
(\mathrm{gr})\end{array}$ & $\begin{array}{c}\text { Massa } \\
\text { Kering } \\
\text { (gr) }\end{array}$ & $\begin{array}{c}\text { Penyerapan } \\
\text { Air } \\
(\%)\end{array}$ & $\begin{array}{c}\text { Penyerapan } \\
\text { Air rata- } \\
\text { rata }(\%)\end{array}$ \\
\hline \multirow{3}{*}{$0 \%$} & C11 & 4634 & 4310 & 7,51 & \multirow{3}{*}{7,53} \\
\hline & C12 & 4498 & 4153 & 8,30 & \\
\hline & C13 & 4583 & 4292 & 6,78 & \\
\hline \multirow{3}{*}{$2,5 \%$} & C21 & 4361 & 4150 & 5,08 & \multirow{3}{*}{5,06} \\
\hline & $\mathrm{C} 22$ & 4236 & 4005 & 5,76 & \\
\hline & $\mathrm{C} 23$ & 4318 & 4138 & 4,35 & \\
\hline \multirow{3}{*}{$5,0 \%$} & C31 & 4190 & 3993 & 4,93 & \multirow{3}{*}{4,96} \\
\hline & C32 & 4239 & 4075 & 4,02 & \\
\hline & C33 & 4251 & 4012 & 5,95 & \\
\hline \multirow{3}{*}{$7,5 \%$} & C41 & 4510 & 3986 & 13,14 & \multirow{3}{*}{11,88} \\
\hline & $\mathrm{C} 42$ & 4397 & 3940 & 11,59 & \\
\hline & C43 & 4463 & 4023 & 10,93 & \\
\hline
\end{tabular}

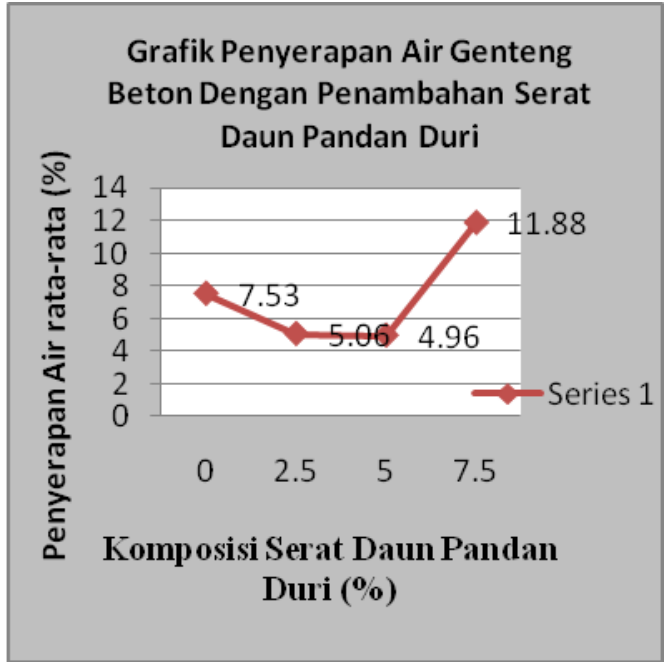

Gambar 4.3. Grafik Penyerapan Air Genteng Beton Dengan Penambahan Serat Daun Pandan Duri
Untuk penyerapan air genteng beton tertinggi terjadi pada komposisi $7,5 \%$ serat daun pandan duri yaitu $11,88 \%$, sedangkan penyerapan air genteng beton terendah terjadi pada komposisi 2,5\% dan 5,0\% serat daun pandan duri yaitu 5,06 \% dan 4,96\% Pada penggunaan campuran serat daun pandan duri $5 \%$ dan 2,5\%, penyerapan air lebih kecil dari genteng beton normal $0 \%$ dan memenuhi syarat mutu SNI 0096:2007. Tetapi pada penambahan serat daun pandan duri $7,5 \%$, penyerapan air tidak memenuhi syarat SNI karena melebih $10 \%$. 


\section{Penyerapan Panas}

Tabel 4.4. Pengujian Penyerapan Panas Genteng Beton dengan Penambahan Serat Daun Pandan Duri dan Pengurangan Pasir

\begin{tabular}{|c|c|c|c|c|c|}
\hline $\begin{array}{l}\text { Komposis } \\
\text { i Serat }\end{array}$ & $\begin{array}{c}\text { Kode } \\
\text { Sampel }\end{array}$ & Termometer & $\begin{array}{c}\text { Penunjukan } \\
\text { Suhu }\left({ }^{0} \mathrm{C}\right)\end{array}$ & $\begin{array}{c}\text { Penyerapan } \\
\text { Panas } \\
\frac{T_{2}}{T_{1}} \times 100 \%\end{array}$ & $\begin{array}{c}\text { Penyerapan } \\
\text { Panas Rata- } \\
\text { rata }(\%)\end{array}$ \\
\hline \multirow{6}{*}{$0 \%$} & \multirow[t]{2}{*}{ D11 } & $\mathrm{T}_{2}$ & 44 & \multirow[t]{2}{*}{73,33} & \multirow{6}{*}{74,3} \\
\hline & & $\mathrm{T}_{1}$ & 60 & & \\
\hline & \multirow[t]{2}{*}{ D12 } & $\mathrm{T}_{2}$ & 44 & \multirow[t]{2}{*}{74,57} & \\
\hline & & $\mathrm{T}_{1}$ & 59 & & \\
\hline & \multirow[t]{2}{*}{ D13 } & $\mathrm{T}_{2}$ & 45 & \multirow[t]{2}{*}{75} & \\
\hline & & $\mathrm{T}_{1}$ & 60 & & \\
\hline \multirow{6}{*}{$2,5 \%$} & \multirow[t]{2}{*}{ D21 } & $\mathrm{T}_{2}$ & 44 & \multirow[t]{2}{*}{74,57} & \multirow{6}{*}{73,86} \\
\hline & & $\mathrm{T}_{1}$ & 59 & & \\
\hline & \multirow[t]{2}{*}{ D22 } & $\mathrm{T}_{2}$ & 43 & \multirow[t]{2}{*}{72,88} & \\
\hline & & $\mathrm{T}_{1}$ & 59 & & \\
\hline & \multirow[t]{2}{*}{ D23 } & $\mathrm{T}_{2}$ & 43 & \multirow[t]{2}{*}{74,13} & \\
\hline & & $\mathrm{T}_{1}$ & 58 & & \\
\hline \multirow{6}{*}{$5,0 \%$} & \multirow[t]{2}{*}{ D31 } & $\mathrm{T}_{2}$ & 42 & \multirow[t]{2}{*}{73,68} & \multirow{6}{*}{73,09} \\
\hline & & $\mathrm{T}_{1}$ & 57 & & \\
\hline & \multirow[t]{2}{*}{ D32 } & $\mathrm{T}_{2}$ & 42 & \multirow[t]{2}{*}{73,68} & \\
\hline & & $\mathrm{T}_{1}$ & 57 & & \\
\hline & \multirow[t]{2}{*}{ D33 } & $\mathrm{T}_{2}$ & 41 & \multirow[t]{2}{*}{71,93} & \\
\hline & & $\mathrm{T}_{1}$ & 57 & & \\
\hline \multirow{6}{*}{$7,5 \%$} & \multirow[t]{2}{*}{ D41 } & $\mathrm{T}_{2}$ & 40 & \multirow[t]{2}{*}{71,42} & \multirow{6}{*}{71,17} \\
\hline & & $\mathrm{T}_{1}$ & 56 & & \\
\hline & \multirow[t]{2}{*}{ D42 } & $\mathrm{T}_{2}$ & 41 & \multirow[t]{2}{*}{71,93} & \\
\hline & & $\mathrm{T}_{1}$ & 57 & & \\
\hline & \multirow[t]{2}{*}{ D43 } & $\mathrm{T}_{2}$ & 40 & \multirow[t]{2}{*}{70,17} & \\
\hline & & $\mathrm{T}_{2}$ & 57 & & \\
\hline
\end{tabular}

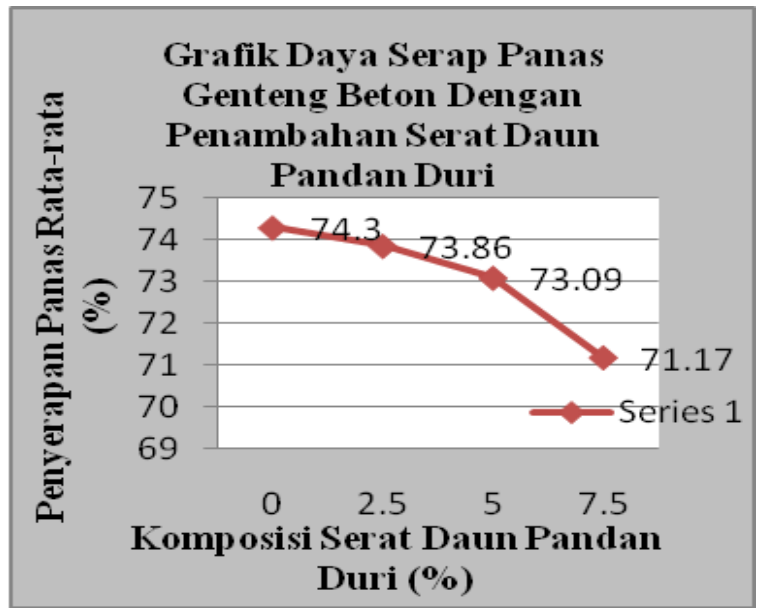

Gambar 4.4. Grafik Daya Serap Panas Genteng Beton Dengan Penambahan Serat Daun Pandan Duri
Dari keempat variasi penambahan serat daun pandan duri dan pengurangan pasir $7,5 \%$ bisa menjadikan ruang yang dinaunginya lebih sejuk, dari pada genteng beton dengan variasi penambahan serat daun pandan duri dan pengurangan pasir $0 \%, 2,5 \%$ dan 5,0\%. Dari hasil pengujian penyerapan panas genteng beton yang telah diuji, telah memenuhi persyaratan pengujian fisika bahan bangunan yaitu tidak lebih dari $75 \%$. 


\section{Berat Genteng Beton dengan Serat Daun Pandan Duri}

Tabel 4.5. Berat Genteng Beton dengan Penambahan Serat Daun Pandan Duri

\begin{tabular}{|c|c|c|c|c|c|}
\hline $\begin{array}{l}\text { Komposisi } \\
\text { Semen }\end{array}$ & $\begin{array}{l}\text { Komposisi } \\
\text { Pasir }\end{array}$ & $\begin{array}{l}\text { Komposisi } \\
\text { Serat }\end{array}$ & Kode Sampel & Massa (gr) & $\begin{array}{c}\text { Massa Rata-rata } \\
\text { (gr) }\end{array}$ \\
\hline \multirow{12}{*}{$25 \%$} & \multirow{3}{*}{$75 \%$} & \multirow{3}{*}{$0 \%$} & C11 & 4346 & \multirow{3}{*}{4430,6} \\
\hline & & & $\mathrm{C} 12$ & 4529 & \\
\hline & & & C13 & 4417 & \\
\hline & \multirow{3}{*}{$72,5 \%$} & \multirow{3}{*}{$2,5 \%$} & $\mathrm{C} 21$ & 4159 & \multirow{3}{*}{4040,6} \\
\hline & & & $\mathrm{C} 22$ & 3977 & \\
\hline & & & $\mathrm{C} 23$ & 3986 & \\
\hline & \multirow{3}{*}{$70 \%$} & \multirow{3}{*}{$5,0 \%$} & C31 & 3891 & \multirow{3}{*}{3942,3} \\
\hline & & & C32 & 4011 & \\
\hline & & & C33 & 3925 & \\
\hline & \multirow{3}{*}{$67,5 \%$} & \multirow{3}{*}{$7,5 \%$} & $\mathrm{C} 41$ & 3896 & \multirow{3}{*}{3983} \\
\hline & & & $\mathrm{C} 42$ & 3872 & \\
\hline & & & $\mathrm{C} 43$ & 3980 & \\
\hline
\end{tabular}

\section{Kesimpulan}

Dari data hasil penelitian dan pembahasan hasil penelitian, maka dapat diambil kesimpulan sebagai berikut:

1. Pengaruh serat daun pandan duri terhadap karakteristik genteng beton yaitu pada kekuatan lentur genteng beton semakin besar penambahan serat daun pandan duri maka kekuatan lentur genteng beton yang dihasilkan menurun . Pada kekuatan impak genteng beton semakin besar penambahan serat daun pandan duri maka kekuatan impak genteng beton yang dihasilkan semakin besar pula. Sedangkan pada penyerapan air dan penyerapan panas genteng beton semakin besar penambahan serat daun pandan duri maka penyerapan air dan penyerapan panas genteng beton genteng beton yang dihasilkan menurun.

2. Hasil pengujian mekanik yaitu kekuatan lentur genteng beton serat daun pandan duri yang tertinggi adalah pada komposisi penambahan serat $25 \%$ yaitu sebesar 13,15 $\pm 0,26 \mathrm{Nmm}^{-2}$. Hasil pengujian mekanik yaitu kekuatan impak genteng beton serat daun pandan duri yang tertinggi adalah pada komposisi persentase serat $75 \%$ yaitu sebesar $6850 \pm 526,78$ Joule $/ \mathrm{m}^{2}$. Sedangkan hasil pengujian fisis yaitu daya serap air genteng beton serat daun pandan duri yang terendah adalah pada komposisi persentase serat 5,0\% yaitu sebesar 4,96 $\pm 0,96 \%$ dan hasil pengujian fisis yaitu daya serap panas genteng beton serat daun pandan duri yang terendah adalah $70,17 \pm 0,90 \%$.

3. Kualitas genteng beton dengan penambahan serat daun pandan duri sesuai dengan yang diharapkan yaitu telah memenuhi syarat-syarat mutu genteng beton dan jauh lebih baik dibandingkan dengan genteng beton normal . Dimana hasil pengujian kekuatan lentur genteng beton normal $0 \%$ serat daun pandan duri yaitu sebesar 1,71 $\mathrm{Nmm}^{-2}$. Hasil pengujian kekuatan impak 
genteng beton normal yaitu sebesar 1216,67 Joule/m². Dan hasil pengujian daya serap air dan daya serap panas genteng beton normal yaitu $7,53 \%$ dan $74,3 \%$.

\section{DAFTAR PUSTAKA}

Andre (2012), http://andre4088.blogsp ot.com/2012/08/manfaattanaman-pandanus.html (diakses tanggal 25 Juni 2013).

Saragih, Deli Natalia., (2007). Pembuatan Dan Karakteristik Genteng Beton Yang Dibuat Dari Pulp Serat Daun NenasSemen Portland Pozolan., Skripsi, Jurusan Fisika, Universitas Sumatera Utara (USU), Medan.
Siregar, V., (2008), Pengaruh Lebar Serat terhadap Sifat Mekanik Komposit Serat Pandan dengan Menggunakan Matriks Epoksi., Skripsi, FMIPA, Unimed, Medan.

Supatmi, (2011), Analisis Kualitas Genteng Beton Dengan Bahan Tambah Serat Ijuk Dan Pengurangan Pasir., Skripsi, Jurusan Teknik Sipil, Universitas Negeri Yogyakarta, Yogyakarta.

Tjitrosoepomo, G., (2007), Taksonomi Tumbuhan (Spermatophyta), Gadjah Mada University Press, Yogyakarta.

Winarni, Ina dan Totok K. Waluyo., (2006), Peningkatan Teknik Pengolahan Pandan (Bagian I) : Pewarnaan Dan Pengeringan, Journal of Chemical 